\title{
Social Media for Teaching and Learning within Higher Education Institution: A Bibliometric Analysis of the Literature (2008-2018)
}

\author{
https://doi.org/10.3991/ijim.v12i7.9634 \\ Kamarul Faizal Hashim( $\left.{ }^{\bowtie}\right)$ \\ University of Dubai, Dubai, UAE \\ kbinhashimeud.ac.ae \\ Ammar Rashid \\ Ajman University, Ajman, UAE \\ Shadi Atalla \\ University of Dubai, Dubai, UAE
}

\begin{abstract}
Research on the topic of social media for teaching and learning in the higher education have received much attention from academia and practitioners. Social media technology was acknowledged not only as an important communication tool between faculty members and students but also shows great potential as the next social learning platform that better serves the teaching, learning and administration of a higher education institute. Its informal setting allows more flexibility for both students and faculty members to teach and learn anywhere and everywhere. Despite its important, little is known about how this research topic is evolving within the literature. Hence, using a bibliometric analysis technique this study examines the trends, topics, and challenges addressed by previous research for the past ten years (2008-2018). The paper ends by discussing future research directions related to this topic.
\end{abstract}

Keywords - Social media technology, higher education, teaching and learning bibliometric analysis.

\section{Introduction}

The use of social media for teaching and learning activities among the faculty members in higher education institution (HEI) has been widely reported in academic manuscripts published in journals and conference proceedings. The use of social media was reported not only to improve communication channels among students and faculty members but also said to impact student's academic performance, student's engagement, and support teaching and learning activities [1][2][3].

The new generation of students whom social media have heavily penetrated their lives has transformed the teaching delivery approaches [4]. HEI integrated the use of 
social media with their existing learning management system platform to provide students with better learning experiences. This education transformation is essential as it helps to centre the effort to promote better engagement between students and learning activities [5]. Through active engagement, it can help to improve students' academic performances [6].

Despite the impacts of social media on teaching and learning activities in HEI, the acceptance and adoption of this technology in teaching and learning context is still not well understood [7]. According to [7], the use of social media technology by students and faculty members are closely associated for personal and professional purposes. Ironically, the frequency of using this technology for teaching and learning purposes is low and only limited to only small group of students (not campus-wide).

Therefore, this study is designed to examine the evolution of this research topic within the literature. The outcome of this paper is essential to help researchers and practitioners to understand the research topic better and made significant contributions to the body of knowledge.

In order to achieve the objective mentioned above, this study adopts a bibliometric analysis method to discuss the development and growth of the research topic within the literature. This method is suitable to map the development and structure of a scientific field [8] and widely adopted by most of the previous researchers. Based on the analysis, this study suggests future directions of this research topic.

In summary, this paper starts by discussing its research motivation (this section), followed by a section that elaborates on the research methodology adopted in this study, then a section discussing the outcome of the research findings, a section articulating the future direction of this research topic and ended with a section that concludes this research paper.

\section{Research Method}

In this study, the manuscripts were searched using Google Scholar as the source database. This database is used over others as this topic is still at its infancy level. Limiting them to specific databases (e.g., SCI, SSCI) might restrict the manuscripts selection process. 'Social media', 'higher education', 'teaching and learning' and 'university' were used as keywords during the searching process. A total of 1, 373 manuscripts were found in the database using these keywords. The manuscript searching process was conducted from $1^{\text {st }}$ February to $30^{\text {th }}$ March 2018.

From the list of manuscripts, papers that fulfil the following criterion were shortlisted and downloaded for analysis:

1. the manuscript's title should reflect a research work that focuses on social media in teaching and learning within higher education context; and

2. have empirical findings; or

3. a literature analysis; and

4. published between the year of 2008 to 2018 ; and

5. published as either a journal article, or a conference proceeding or a book chapter. 
Based on the above criterion, a total of 94 manuscripts were downloaded and analysed for this study. All retrieved information about the manuscripts were preprocessed to remove redundant information. The similar manuscript that was published either as a conference paper or a journal article was consolidated by selecting manuscript published as a journal article. The processed data were aggregated into a database which includes information such as article id number, article title, abstract, source journal, institution, country, and publication's year.

\subsection{Bibliometric Analysis}

Bibliometric analysis is a method uses to give an insight into the growth of literature and the flow of knowledge within a specified field of research. This method uses empiric data and quantitative analysis to trace formal communications in the form of published literature [8]. The output of the analysis is helpful to provide the trends and patterns of publications within the research topic. This study examines the trends of this topic by analysing the distributions of the manuscript by year, types, countries and institutions. This study also categorised previous research based on themes emerging from the publications. Text analysis was conducted on the title and abstract of each manuscript in understanding the theme of the research documents.

\section{$3 \quad$ Findings}

\subsection{Publication by Year and Document Types}

The number of publications related to this topic is showing a decreasing pattern starting from the year 2012 to 2016 . However, in 2017 the pattern changed where the interest in this topic starts to increase. Until mid of 2018 (when this research is conducted), the number of publications related to this topic is 9 and this positive trend most likely to continue. The majority $(85 \%)$ of the manuscripts are published as a journal article. All the manuscripts are written in English. Figure 1 shows the trend of distribution of manuscript by year.

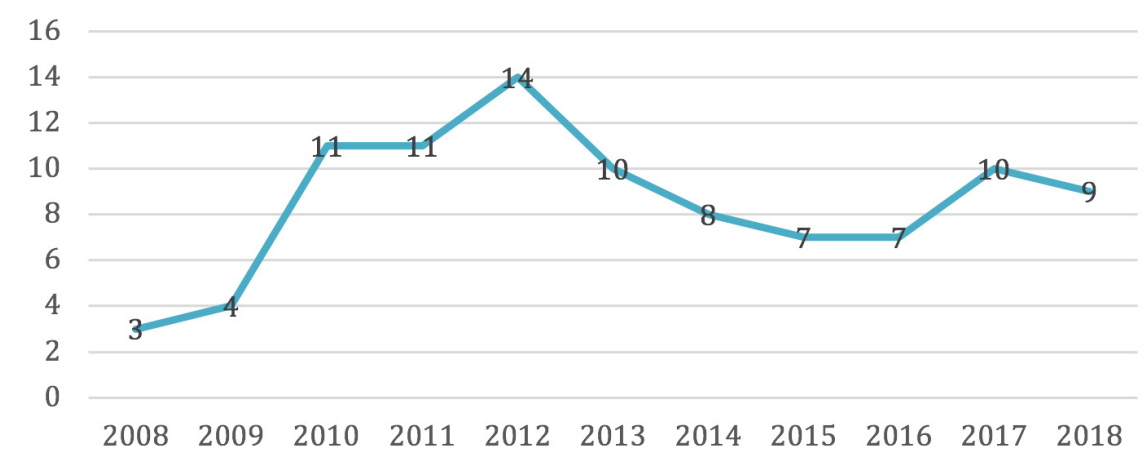

Fig. 1. Distribution of manuscript by years 


\subsection{Distribution by Countries and Institution}

Figure 2 shows the distribution of the countries publishing manuscript related to the topic. Most of the researchers are coming from USA, United Kingdom, Malaysia, Australia, Canada, Italy, South Africa, Egypt, Ireland and Jordan. In total researchers from 25 countries across the world focus on this topic. The top 6 institutions publishing research related to this topic are from Michigan State University (USA), St John University (USA), University of Florance (Italy), Ryerson University (USA), University of South Australia, and Universiti of Malaya (Malaysia). This topic is an interest of researchers coming from both developed and developing countries.

25

20

15

10

5

0

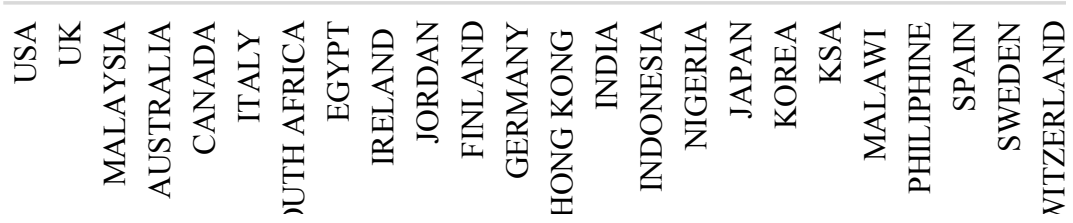

Fig. 2. Distribution of manuscript by countries

\subsection{Distribution by Social Media Application}

Figure 3 shows the distributions of social media application used by researchers when conducting their research. The majority $(30 \%)$ of the publications focus on the use of social media application in general. They examined this topic broadly without specifying on any specific social media application. The remaining $70 \%$ of the publications focus on a specific social media application when conducting their research.

Twenty-three percent of the publications focus on the use of Twitter, 20 percent focus on the use of Facebook, 10 percent focus on the use of weblog and 9 percent of the publications focus on Youtube. The remaining of the publications focus on an application such as Whatsapp (3\%) and customised social media application (5\%). 


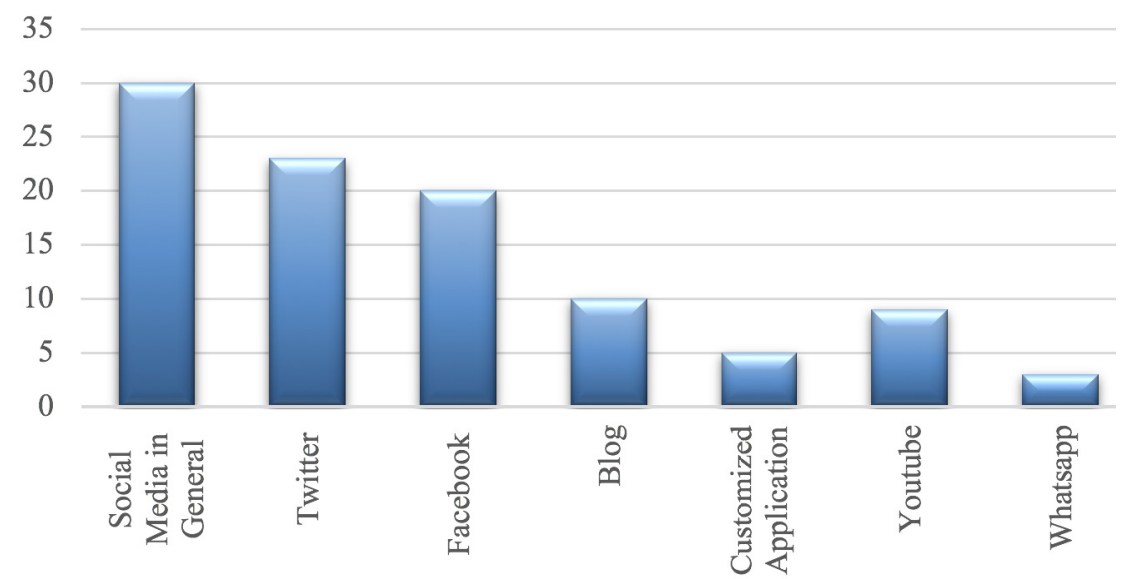

Fig. 3. Distribution by the social media application

\subsection{Distribution of Research Methods}

Figure 4 shows the distribution of research method(s) used by researchers when examining the topic. The majority $(40 \%)$ of the research adopted a quantitative research methodology. The survey approach was used as the primary data collection technique. Twenty-five percent of the researchers adopted a qualitative research methodology. Using this methodology, the researchers collected data using face to face interviews, observations (ethnography) techniques. Fifteen percent of the researchers adopted an experimental research methodology, and the remaining (10\%) of the researchers adopted mixed research methodology where they combined both survey and interviews approaches to collect data from respondents.

Interestingly, within the quantitative research methodology approach, researchers are using data science approach to get a better feel of the data generated by the respondents using social media applications. These researchers adopted data mining and social network analysis to analyse the secondary data generated from the interactions generated from the respondents.

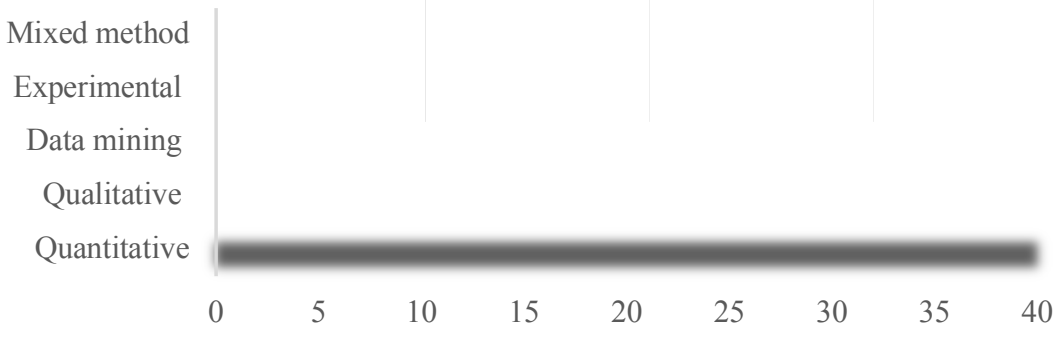

Fig. 4. Distribution of research methods 


\subsection{Distribution of Research Focus}

Table 1 listed a summary of the research focuses on previous research within this research topic. The following sub-sections analysed the trend and topics of this research area.

Table 1. Summary of research focus by previous studies (* JA- Journal article, CP- Conference paper, $\mathrm{BC}-\mathrm{Book}$ chapter)

\begin{tabular}{|c|c|c|c|c|c|}
\hline & $\begin{array}{l}\text { Au- } \\
\text { thors }\end{array}$ & $\begin{array}{l}\text { Social Media } \\
\text { Platform }\end{array}$ & Research Focus & Research Method & $\begin{array}{l}\text { Paper } \\
\text { Type }\end{array}$ \\
\hline 1 & [9] & Blog & $\begin{array}{l}\text { Examine the use of a web blog as } \\
\text { academic resources in a large-cohort } \\
\text { of first-year students. }\end{array}$ & $\begin{array}{l}\text { Observed online usage, } \\
\text { analysed the blog content } \\
\text { posted by the students }\end{array}$ & JA \\
\hline 2 & {$[10]$} & $\mathrm{Blog}$ & $\begin{array}{l}\text { Examine the actual use of weblog in } \\
\text { class towards improving a better } \\
\text { learning experience. }\end{array}$ & $\begin{array}{l}\text { Observed and analysed the } \\
\text { blog's activities and artefacts, } \\
\text { interviewed } 50 \text { selected stu- } \\
\text { dents }\end{array}$ & JA \\
\hline 3 & {$[11]$} & Facebook & $\begin{array}{l}\text { Examine the use of Facebook } \\
\text { among students and faculty } \\
\text { members. }\end{array}$ & $\begin{array}{l}\text { Interviewed } 50 \text { students and } \\
\text { faculty members }\end{array}$ & JA \\
\hline 4 & {$[12]$} & $\begin{array}{l}\text { Youtube \& } \\
\text { Facebook }\end{array}$ & $\begin{array}{l}\text { Explore the role of social media in } \\
\text { involving undergraduate students in } \\
\text { a centred learning environment. }\end{array}$ & $\begin{array}{l}\text { Observed } 131 \text { undergraduate } \\
\text { students usage behaviour com- } \\
\text { pleting their assignment }\end{array}$ & $\mathrm{CP}$ \\
\hline 5 & [13] & Facebook & $\begin{array}{l}\text { Compare the differences in usage } \\
\text { between students and faculty mem- } \\
\text { bers in a university }\end{array}$ & $\begin{array}{l}\text { Surveyed } 120 \text { students and } 62 \\
\text { faculty members. }\end{array}$ & JA \\
\hline 6 & [14] & $\begin{array}{l}\text { Customised } \\
\text { social media } \\
\text { application }\end{array}$ & $\begin{array}{l}\text { Examine the effects of interventions } \\
\text { (based on sense of community fea- } \\
\text { tures) that was designed to promote } \\
\text { effective social media usage for } \\
\text { learning purposes. }\end{array}$ & $\begin{array}{l}\text { Observed the network activities } \\
\text { based on the executed interven- } \\
\text { tions. }\end{array}$ & $\mathrm{CP}$ \\
\hline 7 & [15] & $\begin{array}{l}\text { Social media } \\
\text { in general }\end{array}$ & $\begin{array}{l}\text { Examine the strengths, weaknesses, } \\
\text { opportunities and threats using so- } \\
\text { cial media for teaching and learning } \\
\text { in HEI. }\end{array}$ & $\begin{array}{l}\text { Interviewed } 40 \text { actual initiatives } \\
\text { of social media adoption by } \\
\text { UK-based HEI. }\end{array}$ & JA \\
\hline 8 & {$[16]$} & Twitter & $\begin{array}{l}\text { Analyse the use of microblogging } \\
\text { application to examine the learning } \\
\text { process that takes place among stu- } \\
\text { dents in HEI }\end{array}$ & $\begin{array}{l}\text { Analyzed the microblogging } \\
\text { posts among } 32 \text { students that } \\
\text { take place for } 70 \text { days. }\end{array}$ & JA \\
\hline 9 & [17] & $\begin{array}{l}\text { Social media } \\
\text { in general }\end{array}$ & $\begin{array}{l}\text { Examine the effect of social media } \\
\text { as a supportive communication tool } \\
\text { to promote sense of community and } \\
\text { community of practice in a class- } \\
\text { room. }\end{array}$ & $\begin{array}{l}\text { Surveyed } 72 \text { undergraduate stu- } \\
\text { dents in Taiwan }\end{array}$ & JA \\
\hline 10 & {$[18]$} & $\begin{array}{l}\text { Social media } \\
\text { in general }\end{array}$ & $\begin{array}{l}\text { Investigate the antecedents and } \\
\text { consequences of social media } \\
\text { utilisation in teaching by faculty } \\
\text { members. }\end{array}$ & Surveyed 249 faculty members & JA \\
\hline 11 & [19] & $\begin{array}{l}\text { Social media } \\
\text { in general }\end{array}$ & $\begin{array}{l}\text { Examine the usability of social me- } \\
\text { dia to support collaborative learning } \\
\text { between in-campus and out-campus } \\
\text { students. }\end{array}$ & $\begin{array}{l}\text { Observed the usage of students } \\
\text { to complete the collaborative } \\
\text { task }\end{array}$ & JA \\
\hline
\end{tabular}




\begin{tabular}{|c|c|c|c|c|c|}
\hline & $\begin{array}{l}\text { Au- } \\
\text { thors }\end{array}$ & $\begin{array}{l}\text { Social Media } \\
\text { Platform }\end{array}$ & Research Focus & Research Method & $\begin{array}{l}\text { Paper } \\
\text { Type }\end{array}$ \\
\hline 12 & {$[20]$} & $\begin{array}{l}\text { Social media } \\
\text { in general }\end{array}$ & $\begin{array}{l}\text { Examine faculty members' aware- } \\
\text { ness of social media and use of so- } \\
\text { cial media for personal, professional } \\
\text { and teaching purposes. }\end{array}$ & $\begin{array}{l}\text { Surveyed faculty members in } \\
\text { the US }\end{array}$ & $\mathrm{BC}$ \\
\hline 13 & [21] & $\begin{array}{l}\text { Social media } \\
\text { in general }\end{array}$ & $\begin{array}{l}\text { Examine the effect of social media } \\
\text { on the new student's intellectual and } \\
\text { social lives when adjusting their life } \\
\text { in university. }\end{array}$ & $\begin{array}{l}\text { Surveyed } 256 \text { new students in } \\
\text { US university }\end{array}$ & JA \\
\hline 14 & {$[22]$} & Twitter & $\begin{array}{l}\text { Demonstrate the twitter's function- } \\
\text { alities and proposed strategies to in- } \\
\text { crease class engagement using twit- } \\
\text { ter }\end{array}$ & Case study & $\mathrm{CP}$ \\
\hline 15 & {$[23]$} & Twitter & $\begin{array}{l}\text { Demonstrate how Twitter is used as } \\
\text { an educational tool to help engage } \\
\text { students and to mobilise faculty into } \\
\text { a more active and participatory role. }\end{array}$ & $\begin{array}{l}\text { Conducted series of experi- } \\
\text { ments on } 125 \text { first-year students }\end{array}$ & JA \\
\hline 16 & [24] & $\begin{array}{l}\text { Social media } \\
\text { in general }\end{array}$ & $\begin{array}{l}\text { Examine the faculty members per- } \\
\text { sonal development as preparation to } \\
\text { adopt social media technology for } \\
\text { teaching }\end{array}$ & $\begin{array}{l}\text { Interviewed } 24 \text { chairs and pro- } \\
\text { gram director in a university in } \\
\text { the UK }\end{array}$ & JA \\
\hline 17 & {$[25]$} & $\begin{array}{l}\text { Facebook \& } \\
\text { Blog }\end{array}$ & $\begin{array}{l}\text { Investigate the use of the social } \\
\text { technology in teaching and learning } \\
\text { (understand the context and chal- } \\
\text { lenges) and examine the impact of } \\
\text { this technology towards enhancing } \\
\text { students learning }\end{array}$ & $\begin{array}{l}\text { Interviewed students and lectur- } \\
\text { ers at a university in South Af- } \\
\text { rica }\end{array}$ & JA \\
\hline 18 & {$[26]$} & Twitter & $\begin{array}{l}\text { Demonstrate an empirical evident } \\
\text { how twitter could be used to support } \\
\text { active learning outside the } \\
\text { classroom }\end{array}$ & $\begin{array}{l}\text { Conducted a series of experi- } \\
\text { ments with } 15 \text { students }\end{array}$ & JA \\
\hline 18 & [27] & $\begin{array}{l}\text { Social media } \\
\text { in general }\end{array}$ & $\begin{array}{l}\text { Evaluate how six social media } \\
\text { technologies are used by faculty } \\
\text { members and students in } 3 \\
\text { Australian universities. }\end{array}$ & $\begin{array}{l}\text { Surveyed and interviewed the } \\
\text { students and faculty members } \\
\text { from } 3 \text { universities. }\end{array}$ & JA \\
\hline 19 & [28] & $\begin{array}{l}\text { Social media } \\
\text { in general }\end{array}$ & $\begin{array}{l}\text { Examine the role of social media } \\
\text { application to support the imple- } \\
\text { mentation of social constructivist } \\
\text { pedagogy towards contributing bet- } \\
\text { ter academic achievement }\end{array}$ & $\begin{array}{l}\text { Surveyed } 105 \text { accounting stu- } \\
\text { dents in a university in Spain }\end{array}$ & JA \\
\hline 20 & [29] & $\begin{array}{l}\text { Customized } \\
\text { social media } \\
\text { application }\end{array}$ & $\begin{array}{l}\text { Investigate the faculty members ex- } \\
\text { periences using social media tech- } \\
\text { nology for teaching purposes }\end{array}$ & $\begin{array}{l}\text { Interviewed ten faculty mem- } \\
\text { bers }\end{array}$ & JA \\
\hline 21 & [30] & $\begin{array}{l}\text { Social media } \\
\text { in general }\end{array}$ & $\begin{array}{l}\text { Predicte the influence of technology } \\
\text { adoption based antecedents on the } \\
\text { faculty member's technology } \\
\text { utilisation. }\end{array}$ & $\begin{array}{l}\text { Surveyed } 249 \text { faculty members } \\
\text { in a university in the US. }\end{array}$ & JA \\
\hline 22 & [31] & $\begin{array}{l}\text { Social media } \\
\text { in general }\end{array}$ & $\begin{array}{l}\text { Explore the previous literature to } \\
\text { understand the role of social media } \\
\text { in the higher education classroom. }\end{array}$ & Literature review & JA \\
\hline 23 & {$[32]$} & Twitter & $\begin{array}{l}\text { Compare the differences in aca- } \\
\text { demic use of Twitter between stu- } \\
\text { dents and faculty members }\end{array}$ & $\begin{array}{l}\text { Surveyed } 181 \text { students and fac- } \\
\text { ulty members in a university in } \\
\text { the UK }\end{array}$ & JA \\
\hline
\end{tabular}




\begin{tabular}{|c|c|c|c|c|c|}
\hline & $\begin{array}{l}\text { Au- } \\
\text { thors }\end{array}$ & $\begin{array}{l}\text { Social Media } \\
\text { Platform }\end{array}$ & Research Focus & Research Method & $\begin{array}{c}\text { Paper } \\
\text { Type }\end{array}$ \\
\hline 24 & {$[33]$} & Twitter & $\begin{array}{l}\text { Investigate the factors that contrib- } \\
\text { uted to the reasons why faculty } \\
\text { members are using Twitter and how } \\
\text { they are using it in a higher educa- } \\
\text { tion setting. }\end{array}$ & $\begin{array}{l}\text { Surveyed } 755 \text { faculty members } \\
\text { and educators }\end{array}$ & JA \\
\hline 25 & {$[34]$} & $\begin{array}{l}\text { Social media } \\
\text { in general }\end{array}$ & $\begin{array}{l}\text { Examine how students managed the } \\
\text { information available on social me- } \\
\text { dia as their source of academic in- } \\
\text { formation }\end{array}$ & $\begin{array}{l}\text { Surveyed } 845 \text { undergraduate } \\
\text { students in the US. }\end{array}$ & JA \\
\hline 26 & {$[35]$} & Whatsapp & $\begin{array}{l}\text { Investigate the varieties of } \\
\text { informality discourse between } \\
\text { Saudi's instructors and students. }\end{array}$ & $\begin{array}{l}\text { Analysed } 157,000 \text { posting from } \\
10 \text { WhatsApp groups. }\end{array}$ & $\mathrm{CP}$ \\
\hline 27 & {$[4]$} & $\begin{array}{l}\text { Social media } \\
\text { in general }\end{array}$ & $\begin{array}{l}\text { Examine the faculty members level } \\
\text { of social media adoption for teach- } \\
\text { ing and learning }\end{array}$ & $\begin{array}{l}\text { Surveyed } 120 \text { faculty members } \\
\text { in a university in Malaysia }\end{array}$ & JA \\
\hline 28 & {$[36]$} & Facebook & $\begin{array}{l}\text { Evaluate empirically the influence } \\
\text { of using Facebook to increase stu- } \\
\text { dent engagement and understanding }\end{array}$ & $\begin{array}{l}\text { Conducted series of experi- } \\
\text { ments with } 1,200 \text { students. }\end{array}$ & JA \\
\hline 29 & {$[37]$} & $\begin{array}{l}\text { Social media } \\
\text { in general }\end{array}$ & $\begin{array}{l}\text { Investigate the motivational factors } \\
\text { that contribute to students engage- } \\
\text { ment with social media as a learning } \\
\text { platform }\end{array}$ & $\begin{array}{l}\text { Surveyed } 99 \text { undergraduate stu- } \\
\text { dents in a UK university }\end{array}$ & JA \\
\hline 30 & {$[38]$} & Facebook & $\begin{array}{l}\text { Examine innovative pedagogy that } \\
\text { supports the use of Facebook as a } \\
\text { co-learning community }\end{array}$ & Online ethnography & JA \\
\hline 31 & [39] & $\begin{array}{l}\text { Customized } \\
\text { social media } \\
\text { platform }\end{array}$ & $\begin{array}{l}\text { Explore the flow and exchange of } \\
\text { information among students using } \\
\text { university managed social media } \\
\text { platform }\end{array}$ & $\begin{array}{l}\text { Analyzed students interaction } \\
\text { with the platform using data } \\
\text { mining technique }\end{array}$ & JA \\
\hline 32 & {$[40]$} & $\begin{array}{l}\text { Social media } \\
\text { in general }\end{array}$ & $\begin{array}{l}\text { Explore the motivation, use, prac- } \\
\text { tices and challenges faced by faculty } \\
\text { members using social media for } \\
\text { teaching }\end{array}$ & $\begin{array}{l}\text { Surveyed } 6139 \text { faculty mem- } \\
\text { bers across universities in Italy }\end{array}$ & JA \\
\hline 33 & [41] & $\begin{array}{l}\text { Social media } \\
\text { in general }\end{array}$ & $\begin{array}{l}\text { Explore the use of social media and } \\
\text { investigated the challenges faced by } \\
\text { faculty members in Egypt. }\end{array}$ & $\begin{array}{l}\text { Surveyed } 190 \text { faculty members } \\
\text { from } 8 \text { universities in Egypt. }\end{array}$ & JA \\
\hline 34 & [3] & Wikipedia & $\begin{array}{l}\text { Investigate the acceptance of stu- } \\
\text { dents using Wikipedia for teaching } \\
\text { and learning purposes }\end{array}$ & $\begin{array}{l}\text { Surveyed } 113 \text { students from a } \\
\text { university in South Africa. }\end{array}$ & JA \\
\hline 35 & {$[6]$} & $\begin{array}{l}\text { Social media } \\
\text { in general }\end{array}$ & $\begin{array}{l}\text { Examine the effect of social media } \\
\text { usage and multitasking behaviour } \\
\text { on academic performance }\end{array}$ & $\begin{array}{l}\text { Surveyed } 348 \text { undergraduate } \\
\text { students from } 8 \text { universities in } \\
\text { Hong Kong }\end{array}$ & JA \\
\hline 36 & {$[2]$} & Facebook & $\begin{array}{l}\text { Examine the determinants of SM } \\
\text { adoption using Technology ac- } \\
\text { ceptance model \& E-learning ac- } \\
\text { ceptance model. }\end{array}$ & $\begin{array}{l}\text { Surveyed } 300 \text { students from a } \\
\text { university in Malaysia }\end{array}$ & JA \\
\hline 37 & [1] & $\begin{array}{l}\text { Social media } \\
\text { in general }\end{array}$ & $\begin{array}{l}\text { Investigate the effect of social me- } \\
\text { dia usage on academic performance } \\
\text { from Constructivism Theory \& } \\
\text { Technology Acceptance Model per- } \\
\text { spectives }\end{array}$ & $\begin{array}{l}\text { Surveyed } 723 \text { undergraduate } \\
\text { students from } 5 \text { different uni- } \\
\text { versities }\end{array}$ & JA \\
\hline
\end{tabular}


Paper-Social Media for Teaching and Learning within Higher Education Institution: A Bibliometric ...

\begin{tabular}{|c|c|c|l|l|c|}
\hline $\begin{array}{c}\text { Au- } \\
\text { thors }\end{array}$ & $\begin{array}{c}\text { Social Media } \\
\text { Platform }\end{array}$ & \multicolumn{1}{|c|}{ Research Focus } & Research Method & $\begin{array}{c}\text { Paper } \\
\text { Type }\end{array}$ \\
\hline 38 & {$[42]$} & Whatsapp & $\begin{array}{l}\text { Evaluate the effects of using social } \\
\text { media for academic monitoring, } \\
\text { counselling and tutoring of univer- } \\
\text { sity students. }\end{array}$ & $\begin{array}{l}\text { Surveyed 120 undergraduate } \\
\text { students in Spain }\end{array}$ & JA \\
\hline 39 & {$[43]$} & Youtube & $\begin{array}{l}\text { Examine the usage pattern and asso- } \\
\text { ciated factors that influence stu- } \\
\text { dent's acceptance of Youtube as a } \\
\text { complementary learning tool. }\end{array}$ & $\begin{array}{l}\text { Surveyed 321 undergraduate } \\
\text { from a university in Malaysia }\end{array}$ & JA \\
\hline
\end{tabular}

From the literature analysis, previous research can be categorised into four major themes. The themes are 1) impact on teaching and learning, 2) social media use for teaching and learning, 3) students engagement and 4) supporting tool for teaching and learning. These themes were examined from varieties of a research setting, social media applications and research methods. The next subsections discuss each theme separately.

\subsection{Impact on Learning \& Teaching}

Previous studies have shown that the use of social media for teaching and learning have an impact towards student's learning experiences [10][37]. For instance, using a weblog, a student will engage with an active learning environment where they have to read the blogs of others, write a comment, read a comment and provide feedback to the comments [10]. Active interactions and engagement between students and faculty members made students feel that they are engaging themselves in learning activities. This is essential to provide students with positive learning experiences as they feel they are not left out in class [37].

Besides that, social media is also reported to improve student's academic achievement [6]. According to [6], using social media, it required the students to be multitasking. Social media multitasking behaviour helps the students to achieve better academic performance. Through multitasking behaviour, a student will be more alert of their studies as they need to focus on completing dual tasks and also continuously give attention to the tasks they need to complete. Hence, this behaviour is preferable for academic achievement.

Social media is also reported to improve student's flow and exchange of information between students [39]. Rapid exchange of information help students to be updated with the assigned academic tasks. This active exchange of information is essential to promote active learning environment [23]. Social media is also said to be a dynamic source of learning among the students [34]. Through social media, students can get background information on the subject matter, glean on others' opinion or find solutions or how-to instructions. According to [34] social media can provide information that traditional resources cannot efficiently provide.

Content analysis of student's microblogging post showed that social media application was used to support learning activities informally [16]. Undergraduate students are using social media application for private informal communication when working on a project. In addition, to support communication, this application was also identified to 
facilitate students with group works, examine of direct thoughts and cause of learning among students, a reflection of thoughts and steering learning interventions applied in learning activities.

Finally, social media is also identified to help faculty members to implement collaborative and innovative driven pedagogy when teaching in class [28][38]. For instance, using social media faculty members can adopt social constructivism pedagogy which was found to be helpful in helping students achieved better academic performance. According to [28], using this pedagogy student should be able to learn/create meaning from the social interactions that take place between students and faculty members. This pedagogy which focuses on "demand-pull" model of distributing and creating knowledge is suitable for the new generation of students who are technology savvy.

Through the use of social media in the classroom, faculty members can explore and experiment with innovative pedagogy where they can combine traditional pedagogy with social media technology. For instance, [38] combined 'norm-critical' and 'consciousness-raising' pedagogy to stimulate and assist students in learning cooperatively using Facebook. This pedagogy supports a co-learning approach where students help each other during the learning activities.

\subsection{Social Media Use for Teaching and Learning}

Base on the literature analysis, social media adoption can be categorised into two main group of users - 1) among students and 2) among faculty members. From a student adoption point of view, previous researchers put much attention towards understanding: 1) how the students use social media for learning purposes, 2) what are the student's preferable social media applications and 3) how to promote collaborative environment among students by using social media applications [9][11][12][20]. In addition, there are also studies that examined the features of social media applications and suggested strategies that can be applied to promote active participation among students. Previous studies have examined the pattern and trends of social media use within the class, campus-wide and nation-wide settings [1][2][27][41].

From a faculty member adoption point of view, researchers are interested in examining: 1) how faculty members use the social media application, 2) what are the barriers/obstacles and challenges faced by faculty members when using the social media application for teaching and 3) factors that promote use of social media applications among faculty members [18][33][40][41]. Previous studies indicated that faculty adoption of social media is still at the early majority adoption level [4]. At this level of adoption, faculty members agreed on the importance and success of adopting the social media application but, they are still cautious on giving their full commitment and efforts in using this application for teaching purposes.

Previous studies indicated that faculty members are not willing to trade their privacy by 'friending' with their students. Faculty members feel uncomfortable to expose their personal life to their students [40]. Besides privacy threats, faculty members believe that using social media for teaching it might: 1) reduce their teaching role, 2) suitable 
teaching pedagogy, 3) institutional administrative issues in term of policy, infrastructure support, workload issues, ownership of assessment and content shared publicly, etc. [15][40].

Despite the obstacles, faculty members agreed that through social media application it could help better relationship with students, support improvement in learning by promoting collaborative, reflective and independent learning [15]. The use of social media application for teaching can also provide opportunities to create and maintain a community of students and promote class project or assignment indirectly through a network of friends [15].

Majority of previous studies that examine students or faculty members use social media application for teaching and learning usually use a case study of a specific course, class or university. The focus is mainly to demonstrate how the social media applications are used for teaching purposes. There is a need to examine social media application for teaching and learning using theoretical lenses. This approach helps to give a better understanding of students and faculty members adoption behaviour. As per record, very few studies used theoretical lenses to examine students and faculty members adoption behaviour [1][3][4][18].

\subsection{Student Engagement}

The findings of the analysis show that social media is an essential tool used by students and faculty members to better engage with one another. Using social media students and faculty members can communicate informally outside of class period [35]. Although the communication is not at the personal level, social media application was proven to support open discourse between faculty and students. According to [35], although the communication is informal, there is a set of guidelines that need to be followed between two parties. Previous studies also have shown that the use of social media can improve student's engagement with course materials [36]. Providing feedback to questions asked is crucial to increase student's engagement with course materials [26].

In addition to the above, through social media use, it can help promotes positive engagement by shaping a sense of community among students and faculty members. The community of students who are connected with the same goal (i.e., learning) is forming a community of practice (CoP) [17]. Social media application is at the hearth of $\mathrm{CoP}$ as it allows students to expand their knowledge through connections with individuals that have similar interest. According to [17], their research findings demonstrated that using social media in the classroom, students can develop strong social connectedness and expressed favourable feelings regarding their learning experiences in the classes. This positive feeling will make learning a positive experience, as students are willing to help each other due to personal obligations to help others. Using social media application, the students can share information, opinion or feeling easily and openly with their friends. The bonding and binding of relationships that developed between them help enhance the feeling of a sense of community. The feeling of a sense of community is one of the crucial elements that determine the success of an online community [44]. 


\subsection{Supporting Tool for Teaching and Learning}

Under this theme, previous studies examined the role use of social media as a supporting tool to help enhance teaching and learning processes. Compared to other themes, this theme received the least attention by previous researchers [42][43]. From the analysis, social media application was used as an additional communication channel to formal learning management system operated by the higher education management. It was also used as an alternative communication channel to support large classroom and interaction between on-campus and off-campus students [25].

\section{Conclusion}

Despite the interest shown by many researchers for the past decade, it can be concluded that this topic is still under research and at its infancy level. Many empirical studies need to be conducted to support the exploratory findings. Furthermore, most of the findings are based on general surveys and did not back up by strong theoretical articulations. The findings need to be interpreted cautiously, as most of the sample populations are bias and are not generalizable.

In order to contribute to the body of the knowledge, this study proposed few points that can be considered to expand this research topic. Among them are:

1. examine the overall suitability of social media as a teaching and learning platform. Besides focusing on technology adoption-related issues, there is a need to consider the social and management aspects of using this application for teaching and learning purposes. There is a need to examine the effects of social related factors that promote a sense of belonging between students and faculty members. Since this application is socially driven, not being able to understand how social factors affect the usage of this application might not give full understanding on how to optimise the use of this application for teaching and learning.

2. Besides that, understanding the management aspects of adopting social media at an institutional level is also essential to ensure future success. Institutional policies of HEI needs to be social media friendly and most importantly will not add additional workload to both faculty members and students. There is also a need to identify the suitable assessments styles and teaching pedagogy that goes along with teaching activities using social media application. Evaluating informal interactions is a challenge which is worth examining in the future;

3. analyse the performance of social media as teaching and learning tools by giving better analytical insights to both faculty members and students on their performance. This analytical insight is essential to help especially faculty members make better decisions on how to optimise the use of this platform;

4. build up a stronger underlying basis of research on this topic by supporting it with theories. This research topic has a multidimensional perspective where it involves not only students but also faculty members, (formal and informal) community and technology. Examining these multi-dimensional topics from a variety of theoretical lenses can build a better understanding of this topic; and 
5. integrate quantitative and qualitative research methodology with data science approaches (i.e., text mining, sentiment analysis) are highly recommended. Analysing the secondary data (e.g., Facebook posts, tweets) might provide better triangulation on the potential of this platform.

Above all, social media has a significant potential to support ubiquitous learning. The convergence of social media in the new generation of students requires higher education institute to formalise the use of social media in their teaching and learning activities. The new generation of students who are digital natives is very comfortable with social-based technology. Transforming the way education is delivered is essential to make sure students are able to grasp positive learning experiences while studying in a higher education institution.

\section{$5 \quad$ References}

[1] Al-Rahmi, W. M., Alias, N., Othman, M. S., Marin, V. I., \& Tur, G. (2018). A model of factors affecting learning performance through the use of social media in Malaysian higher education. Computers and Education, 121: 59-72 https://doi.org/10.1016/j.compedu.2018. $\underline{02.010}$

[2] Balakrishnan, V. (2017). Key determinants for intention to use social media for learning in higher education institutions. Universal Access in the Information Society, 16(2): 289-301. https://doi.org/10.1007/s10209-016-0457-0

[3] Cilliers, L. (2017). Wiki acceptance by university students to improve collaboration in higher education. Innovations in Education and Teaching International, 54(5): 485-493. https://doi.org/10.1080/14703297.2016.1180255

[4] Hashim, K. F., Zamani, M. A., Othman, F., Othman, Z., \& Azhar, A. (2015). Social media adoption in higher education: A case study of Universiti Utara Malaysia. Jurnal Teknologi, 4 (September): 49-56.

[5] Khan, T., Kend, M., \& Robertson, S. (2016). Use of social media by university accounting students and its impact on learning outcomes. Accounting Education, 25(6): 534-567. https://doi.org/10.1080/09639284.2016.1230880

[6] Lau, W. W. F. (2017). Effects of social media usage and social media multitasking on the academic performance of university students. Computers in Human Behavior, 68: 286-291. https://doi.org/10.1016/j.chb.2016.11.043

[7] Manca, S., \& Ranieri, M. (2016). Facebook and the others. Potentials and obstacles of social media for teaching in higher education. Computers and Education, 95(January): 216-230. https://doi.org/10.1016/j.compedu.2016.01.012

[8] Estabrooks, C. A., Winther, C., \& Derksen, L. (2004). Mapping the field: a bibliometric analysis of the research utilization literature in nursing. Nursing Research, 53(5): 293-303. https://doi.org/10.1097/00006199-200409000-00003

[9] Farmer, B., Yue, A., \& Brooks, C. (2008). Using blogging for higher order learning in large cohort university teaching: A case study Context of case study. World Wide Web Internet and Web Information Systems, 24(2): 123-136.

[10] Churchill, D. (2009). Educational applications of Web 2.0: Using blogs to support teaching and learning. British Journal of Educational Technology, 40(1): 179-183. https://doi.org/10.1111/j.1467-8535.2008.00865.x 
[11] Bosch, T. E. (2009). Using online social networking for teaching and learning: Facebook use at the University of Cape Town. Communicatio, 35(2): 185-200. https://doi.org/10.1080/02500160903250648

[12] Cuevas, A., \& Kohle, F. (2010). A Case Study in Using Youtube and Facebook as Social Media Tools in Enhancing Student Centered Learning and Engagement. In ICERI2010 Proceedings: $3596-3601$.

[13] Roblyer, M. D., McDaniel, M., Webb, M., Herman, J., \& Witty, J. V. (2010). Findings on Facebook in higher education: A comparison of college faculty and student uses and perceptions of social networking sites. Internet and Higher Education, 13(3): 134-140. https://doi.org/10.1016/j.iheduc.2010.03.002

[14] Silius, K., Miilumäki, T., Huhtamäki, J., Tebest, T., Meriläinen, J., \& Pohjolainen, P. (2010). Social media enhanced studying and learning in higher education. In Education Engineering (EDUCON), 2010 IEEE: 137-143. https://doi.org/10.1109/EDUCON.2010.5492586

[15] Schroeder, A., Minocha, S., \& Schneider, C. (2010). The strengths, weaknesses, opportunities and threats of using social software in higher and further education teaching and learning. Journal of Computer Assisted Learning, 26(3): 159-174. https://doi.org/10.1111/j.13 65-2729.2010.00347.x

[16] Ebner, M., Lienhardt, C., Rohs, M., \& Meyer, I. (2010). Microblogs in Higher Education A chance to facilitate informal and process-oriented learning? Computers and Education, 55(1): 92-100. https://doi.org/10.1016/i.compedu.2009.12.006

[17] Hung, H.-T., \& Yuen, S. C.-Y. (2010). Educational use of social networking technology in higher education. Teaching in Higher Education, 15(6): 703-714. https://doi.org/10.1080/ 13562517.2010 .507307

[18] Cao, Y., \& Hong, P. (2011). Antecedents and consequences of social media utilization in college teaching: a proposed model with mixed-methods investigation. On the Horizon, 19(4): 297-306. https://doi.org/10.1108/10748121111179420

[19] Tay, E., \& Allen, M. (2011). Designing social media into university learning: Technology of collaboration or collaboration for technology? Educational Media International, 48(3): 151-163 https://doi.org/10.1080/09523987.2011.607319

[20] Moran, M., Seaman, J., \& Tinti-Kane, H. (2011). Teaching, Learning, and Sharing: How Today's Higher Education Faculty Use Social Media. Babson Survey Research Group, (April), 1-16.

[21] Deandrea, D. C., Ellison, N. B., Larose, R., Steinfield, C., \& Fiore, A. (2012). Serious social media: On the use of social media for improving students' adjustment to college. Internet and Higher Education, 15(1): 15-23. https://doi.org/10.1016/j.iheduc.2011.05.009

[22] Rockinson-Szapkiw, A. J., \& Szapkiw, M. (2011). Engaging Higher Education Students Using Twitter. Proceedings of Global Learn Asia Pacific 2011: 360-364.

[23] Junco, R., Heiberger, G., \& Loken, E. (2011). The effect of Twitter on college student engagement and grades. Journal of Computer Assisted Learning, 27(2): 119-132. https://doi.org/10.1111/j.1365-2729.2010.00387.x

[24] Kukulska-Hulme, A. (2012). How should the higher education workforce adapt to advancements in technology for teaching and learning? Internet and Higher Education, 15(4): 247 254. https://doi.org/10.1016/j.iheduc.2011.12.002

[25] Ivala, E., \& Gachago, D. (2012). Social media for enhancing student engagement: The use of Facebook and blogs at a University of Technology. SAJHE, 26(1): 152-166.

[26] Kassens-Noor, E. (2012). Twitter as a teaching practice to enhance active and informal learning in higher education: The case of sustainable tweets. Active Learning in Higher Education, 13(1): 9-21. https://doi.org/10.1177/1469787411429190 
[27] Bennett, S., Bishop, A., Dalgarno, B., Waycott, J., \& Kennedy, G. (2012). Implementing Web 2.0 technologies in higher education: A collective case study. Computers and Education, 59(2): 524-534. https://doi.org/10.1016/j.compedu.2011.12.022

[28] Arquero, J. L., \& Romero-Frías, E. (2013). Using social network sites in Higher Education: an experience in business studies. Innovations in Education and Teaching International, 50(3): 238-249. https://doi.org/10.1080/14703297.2012.760772

[29] Veletsianos, G., Kimmons, R., \& French, K. D. (2013). Instructor experiences with a social networking site in a higher education setting: Expectations, frustrations, appropriation, and compartmentalization. Educational Technology Research and Development, 61(2): 255278. https://doi.org/10.1007/s11423-012-9284-Z

[30] Cao, Y., Ajjan, H., \& Hong, P. (2013). Using social media applications for educational outcomes in college teaching: A structural equation analysis. British Journal of Educational Technology, 44(4): 581-593. https://doi.org/10.1111/bjet.12066

[31] Tess, P. A. (2013). The role of social media in higher education classes (real and virtual)-A literature review. Computers in Human Behavior, 29(5):60-68. https://doi.org/10.1016/ j.chb.2012.12.032

[32] Knight, C. G., \& Kaye, L. K. (2016). "To tweet or not to tweet?" A comparison of academics' and students' usage of Twitter in academic contexts. Innovations in Education and Teaching International, 53(2): 145-155. https://doi.org/10.1080/14703297.2014.928229

[33] Carpenter, J. P., \& Krutka, D. G. (2014). How and why educators use Twitter: A survey of the field. Journal of Research on Technology in Education, 46(4): 414-434. https://doi.org/10.1080/15391523.2014.925701

[34] Kim, K.-S., Sin, S.-C. J., \& Yoo-Lee, E. Y. (2014). Undergraduates' use of social media as information sources. College \& Research Libraries, 75(4): 442-457. https://doi.org/10.5860/ crl.75.4.442

[35] Alamri, J. (2015). ( In ) formality in Social Media Discourse: The Case of Instructors and Students in Saudi Higher Education. Global Learn Berlin 2015, 16-17 April 2015, Berlin, Germany: 101-108.

[36] Dyson, B., Vickers, K., Turtle, J., Cowan, S., \& Tassone, A. (2015). Evaluating the use of Facebook to increase student engagement and understanding in lecture-based classes. Higher Education, 69(2): 303-313. https://doi.org/10.1007/s10734-014-9776-3

[37] Cooke, S. (2017). Social teaching: Student perspectives on the inclusion of social media in higher education. Education and Information Technologies, 22(1), 255-269. https://doi.org/10.1007/s10639-015-9444-y

[38] Marta, C., Monica, E., Ingegerd, R., \& Ann-Katrin, W. (2016). Using Facebook as a colearning community in higher education. Learning, Media and Technology, 41(1): 55-72. https://doi.org/10.1080/17439884.2015.1064952

[39] Singh, A. (2017). Mining of Social Media data of University students. Education and Information Technologies, 22(4): 1515-1526. https://doi.org/10.1007/s10639-016-9501-1

[40] Manca, S., \& Ranieri, M. (2016). Facebook and the others. Potentials and obstacles of Social Media for teaching in higher education. Computers and Education, 95(February):216-230. https://doi.org/10.1016/i.compedu.2016.01.012

[41] Sobaih, A. E. E., Moustafa, M. A., Ghandforoush, P., \& Khan, M. (2016). To use or not to use? Social media in higher education in developing countries. Computers in Human Behavior, 58: 296-305. https://doi.org/10.1016/i.chb.2016.01.002

[42] Pérez-Jorge, D., Barragán-Medero, F., Gutiérrez-Barroso, J., \& Castro-León, F. (2018). A synchronous tool for innovation and improvement of university communication, counseling and tutoring: The WhatsApp experience. Eurasia Journal of Mathematics, Science and Technology Education, 14(7): 2737-2743. 
[43] Moghavvemi, S., Sulaiman, A., Jaafar, N. I., \& Kasem, N. (2018). Social media as a complementary learning tool for teaching and learning: The case of youtube. International Journal of Management Education, 16(1): 37-42. https://doi.org/10.1016/j.ijme.2017.12.001

[44] Mohd Yusof, S. A., \& Hashim, K. F. (2010). Exploring the Formation of Social Capital in a Malaysia Virtual Community. The Journal of Community Informatics, 10(1). Retrieved from http://ci-journal.org/index.php/ciej/article/view/932 6

\section{Authors}

Kamarul Faizal Hashim, PhD is an Assistant Professor and the Chair of the IT Department, at the College of Engineering \& IT, University of Dubai, UAE. His research interests are in knowledge management, IS adoption behaviour, social media, egovernment, mobile learning, social media analytics and smart city management.

Ammar Rashid, PhD is an Associate Professor at the College of Information Technology, Ajman University, UAE. His research interests are in business process innovation, customer knowledge management, business analytics, big data, data science, enterprise systems, and service systems.

Shadi Atalla, PhD is an Assistant Professor at the College of Engineering \& IT, University of Dubai, UAE. His main research interests are in high speed switching architectures, wireless networks, and Internet of Thing.

Article submitted 03 October 2018. Resubmitted 25 October 2018. Final acceptance 02 November 2018. Final version published as submitted by the authors. 